\title{
Ontogenetic changes in at-sea distributions of immature short-tailed albatrosses Phoebastria albatrus
}

\author{
Rachael A. Orben ${ }^{1, *}$, Amelia J. O'Connor ${ }^{2}$, Robert M. Suryan ${ }^{1,3}$, Kiyoaki Ozaki ${ }^{4}$, \\ Fumio Sato ${ }^{4}$, Tomohiro Deguchi ${ }^{4}$
}

\author{
${ }^{1}$ Department of Fisheries and Wildlife, Oregon State University, Hatfield Marine Science Center, \\ 2030 SE Marine Science Drive, Newport, Oregon 97365, USA \\ ${ }^{2}$ College of Earth, Ocean, and Atmospheric Science, Oregon State University, 104 CEOAS Administration Building, Corvallis, \\ Oregon 97331, USA \\ ${ }^{3}$ NOAA Fisheries, Alaska Fisheries Science Center, Auke Bay Laboratories, Ted Steven's Marine Research Institute, \\ 17109 Pt. Lena Loop Rd., Juneau, Alaska 99801, USA \\ ${ }^{4}$ Division of Avian Conservation, Yamashina Institute for Ornithology, 115 Konoyama, Abiko, Chiba 270-11, Japan
}

\begin{abstract}
The ability of juveniles of wide-ranging species to locate distant foraging regions can rely on innate or learned information. Reliance on innate cues could be problematic when conservation actions facilitate reintroduction. In the North Pacific, the short-tailed albatross Phoebastria albatrus is recovering from extensive harvesting, and has recently benefited from translocation efforts. Yet little is known about how naïve juveniles disperse or about individual distributions of immature short-tailed albatrosses. The primary goals of this study were to quantify the ontogeny of movement patterns and spatial distributions and compare these between naturally reared and translocated short-tailed albatrosses. We tracked 51 albatrosses for up to 5 years post-fledging: naturally reared chicks from their natal colony on Torishima, Japan, and chicks that were translocated $350 \mathrm{~km}$ to the southeast to Mukojima, Japan. Initial, more northerly dispersal of translocated fledglings suggests the ability to adjust to a new departure location. Fledglings' departure paths differed from previously tracked adults departing Torishima, yet like adults, the majority of fledglings $(81 \%)$ reached the Bering Sea that first summer, further supporting large-scale innate orientation abilities. Juveniles showed strong seasonal changes in distributions, traveling more in winter and occupying regions not typically used by adults (e.g. California Current, Sea of Okhotsk). As they aged, juveniles began to exhibit habitat fidelity to shelf-break regions, as anticipated from prior studies, yet continued to explore new regions with low levels of spatial fidelity. Juvenile short-tailed albatrosses explored almost the entire species range, highlighting the impressive capacity of individuals to transverse the North Pacific.
\end{abstract}

KEY WORDS: Post-fledging migration · Juvenile distribution · Dispersal · Year-round tracking • Seabird $\cdot$ Home range $\cdot$ Albatross $\cdot$ GPS tracking

\section{INTRODUCTION}

Juveniles of highly mobile species must successfully navigate migration routes and travel to distant foraging grounds in order to survive. Yet, dispersal and development of foraging skills is often poorly under-

${ }^{*}$ Corresponding author: raorben@gmail.com stood. Dispersal is characterized by direct movement to foraging grounds, suggesting genetic or cultural inheritance of foraging behavior (e.g. McConnell et al. 2002), or seemingly random movements, suggesting individual experience and learning (Guilford et al. 2011, Guilford \& de Perera 2017). For long-lived spe-

() The authors 2018. Open Access under Creative Commons by Attribution Licence. Use, distribution and reproduction are unrestricted. Authors and original publication must be credited. 
cies, both genetics and learning are likely to play an important role in migration and the development of habitat preferences. For example, some seabirds, fledge by themselves or in the company of other naïve individuals, and are thus initially reliant on innate compass directions and responses to environmental cues (Weimerskirch et al. 2006, de Grissac et al. 2016). Over time they then develop foraging strategies that are similar to adults (Riotte-Lambert \& Weimerskirch 2013, de Grissac et al. 2017). Initial reliance on innate cues could potentially be problematic for species that experienced large population declines and extirpation from breeding colonies (Payne 1977, Hucke-Gaete et al. 2004, Le Boeuf et al. 2011), especially when conservation actions facilitate reintroduction through translocations (Deguchi et al. 2012, 2014, 2017). In addition, the importance of learning migration behavior and foraging area selection are likely key components of how marine predators will cope with climate-driven changes to ecosystems (Hazen et al. 2012a). Flexibility may hinge on the capacity of juvenile individuals to explore new regions, in contrast to adults that exhibit restricted ranges and high fidelity to specific foraging areas (Baylis et al. 2012, Costa et al. 2012, Votier et al. 2017).

Juvenile seabirds are free of reproductive constraints, have different energetic requirements, are more naïve than adults, and thus often have distinctive behavior, foraging preferences, and distributions than adults (Wanless \& Harris 1991, Gutowsky et al. 2014a, Fayet et al. 2015). They may also engage in riskier behavior than adults. For many species, survival rates of first-year juveniles are lower than for adults as initial mortality is high (Alderman et al. 2010, Deguchi et al. 2014, VanderWerf \& Young 2016). For long-lived species, such as albatrosses, the immature phase is lengthy (3-12 yr), and these individuals make up a large portion of the population (Porter \& Coulson 1987, Crespin et al. 2006). The recruitment of immature individuals into the breeding populations is key to maintaining populations, and reduced juvenile recruitment is a documented cause of population declines (e.g. Terauds et al. 2006). Similarly, juvenile recruitment can drive variation in population levels (Payo-Payo et al. 2016). Presumably, mortality risk decreases as individuals gain experience (e.g. Fay et al. 2015). In some cases, immature seabirds have a tendency to be more vulnerable to fisheries bycatch than adults (Weimerskirch \& Jouventin 1987, Murray et al. 1993, Bregnballe \& Frederiksen 2006), yet adult individuals are more often caught as fisheries bycatch in temperate and subpolar regions (Gianuca et al. 2017).
Short-tailed albatrosses Phoebastria albatrus, listed as endangered in the United States, Japan, and Canada, and Vulnerable by the IUCN, are in recovery from near extinction due to human exploitation for feathers in the early 19th century (Austin 1949, Hasegawa \& DeGange 1982, Zador et al. 2008). Once, this species was likely the most abundant albatross in the North Pacific, with a population estimated to be in the millions of individuals (Austin 1949, Causey et al. 2005); now the population is estimated to be $\sim 4300$ birds (USFWS 2014). Short-tailed albatrosses breed on subtropical islands; the majority of breeding is limited to 2 islands: Torishima and Minami-kojima. Additional breeding by a handful of pairs has occurred in the northwest Hawaiian Islands (USFWS 2014). Torishima is an active volcano and eruptions pose a potential threat to this species (Finkelstein et al. 2010). Therefore, in February 2008-2012, a total of 70 one month old short-tailed albatrosses were translocated from Torishima to Mukojima, in the Bonin (Ogasawara) Islands, where they were hand-reared to facilitate reestablishment of a historical colony (Deguchi et al. 2012, 2014). Though the islands are in relatively close proximity $(\sim 350 \mathrm{~km})$, the shift in geographic starting point could influence migratory routes and distributions of chicks fledging from the translocation site on Mukojima. As of the 2013-2014 breeding season, at least 2 birds from the translocated cohorts have paired and started breeding on Mukojima and adjacent islands (Deguchi et al. 2017).

Though numbers of short-tailed albatrosses remain comparatively low, the rapid population increase suggests high juvenile survival (Zador et al. 2008), and is one probable cause of range reoccupation in the Bering Sea (Kuletz et al. 2014). High survival suggests efficient foraging strategies or sufficient foraging opportunities during the immature phase. Yet, juvenile short-tailed albatrosses are still the most vulnerable portion of the population to mortality at sea (Suryan et al. 2007, Deguchi et al. 2014). This can partially be explained by higher fisheries overlap (Suryan et al. 2007). Adult short-tailed albatrosses forage over both oceanic and neritic habitats across the North Pacific (Hasegawa \& DeGange 1982, Suryan et al. 2006), concentrating along biologically productive shelf-break areas (Piatt et al. 2006), while juveniles appear to use shelf-based habitats more, especially in the Sea of Okhotsk, Bering Sea, and along the US west coast (Suryan et al. 2007, Deguchi et al. 2014). The risks juveniles encounter are especially pertinent, when considering conservation actions such as translocations and colony reestablishments, as the success of these efforts hinges on juvenile 
birds surviving to enter the breeding population in their new locality (Jones \& Kress 2012).

The primary goals of this study were to quantify the development of movement patterns and spatial distributions of short-tailed albatross fledglings through their initial flight years and compare naturally reared and translocated chicks. In addition, we qualitatively compare and discuss migratory routes and distributions of fledglings and previously tracked adults to better understand the potential for innate orientation and habitat preferences of juvenile birds. These analyses provide new insight into movement patterns of an understudied life history stage (Hazen et al. 2012b) of a species recovering from near extinction, but still less than $1 \%$ of its historical population size.

\section{MATERIALS AND METHODS}

Short-tailed albatross chicks were tagged in early May within 3 wk prior to fledging with solar GPS/ Argos PTT-100 satellite transmitters (Microwave Telemetry), annually from 2008 to 2012 (2008: $\mathrm{n}=10$; 2009: $\mathrm{n}=14 ; 2010: \mathrm{n}=12 ; 2011: \mathrm{n}=14 ; 2012: \mathrm{n}=12)$. Transmitters weighed $22 \mathrm{~g}(<1 \%$ body mass $)$. Each year, 10-15 chicks were translocated from Torishima $\left(30^{\circ} 29^{\prime} \mathrm{N}, 140^{\circ} 18^{\prime} \mathrm{E}\right), 350 \mathrm{~km}$ to the southeast to Mukojima $\left(27^{\circ} 41^{\prime} \mathrm{N}, 142^{\circ} 07^{\prime} \mathrm{E}\right)$. Annually, 40-50\% of the translocated chicks were tagged along with an equivalent number of naturally reared chicks on Torishima (Deguchi et al. 2014). Sex was determined using blood samples and molecular methods (Fridolfsson \& Ellegren 1999).

Transmitters were attached using 2 methods: tape and harnesses. Most transmitters $(\mathrm{n}=46)$ were attached to back feathers using Tesa ${ }^{\circledR}$ tape. Transmitters attached using figure-8 harnesses were fit to 2 birds from each colony, annually (Higuchi et al. 1996, 2004). For this study, we included birds that survived post-fledging to sustained flight (mean speed of $>20 \mathrm{~km} \mathrm{~h}^{-1}$; harness: $\mathrm{n}=15$; tape: $\mathrm{n}=36$; overall $85.5 \%$ ), and excluded locations during the post-fledging 'drift' period $\left(<5 \mathrm{~km} \mathrm{~h}^{-1}\right.$, lasting 8-12 d on average) (Deguchi et al. 2014). The short-tailed albatross population was estimated to be a maximum of 3400 birds during the years of this study, roughly half of which are immature birds (0-7 yr old) (P. Sievert \& H. Hasegawa unpubl. data). Thus, 51 birds represent roughly $3 \%$ of the immature population.

Transmitters recorded up to 6 GPS locations per day at 2 or $4 \mathrm{~h}$ intervals. Locations were transmitted every $3 \mathrm{~d}$ through Service Argos (CLS America). Position accuracy was $<10 \mathrm{~m}$. Erroneous locations, including oc- casional time-related errors $(<3 \%)$, were filtered based on animal speed $\left(<80 \mathrm{~km} \mathrm{~h}^{-1}\right)$ (McConnell et al. 1992) and identification of time-specific errors (Deguchi et al. 2014). We interpolated hourly locations in MATLAB software (MathWorks); however, we did not interpolate locations across gaps $>24 \mathrm{~h}$. The remainder of data processing was done in $\mathrm{R}$ ( $\mathrm{R}$ Core Team 2016). Statistical significance was considered to be $\mathrm{p}<0.05$.

\section{Movements}

We investigated departure angles and path sinuosity for the 3 mo post-fledging to investigate potential consequences of translocation on initial at-sea movements. We quantified departure bearing as the circular mean of each point-to-point absolute direction up to $10 \mathrm{~d}$ after birds obtained sustained flight (de Grissac et al. 2016). We then calculated the bearing (rhumb line) between the colony and locations at the end of June, July, and August along with the associated great-circle distance. Path straightness was calculated as the point-to-point distance divided by the great-circle distance from the initial point to the end point. Circular statistics were used to test for differences in bearings between groups (Agostinelli \& Lund 2013) and ANOVAs were used to test for difference in path straightness. Daily travel rates $(\mathrm{km}$ $\mathrm{d}^{-1}$ ) were calculated for each bird for each day with $>11$ locations and each month with $>9 \mathrm{~d}$. Then, linear mixed models with individual as a random effect were used to test for differences between time periods, colonies, and sex. ANOVA F-test results were used to evaluate factor significance (Bolker et al. 2009).

\section{Spatial distributions}

To assess albatross association with oceanographic habitats, we determined the proportion of albatross hours within continental shelf ( $\geq 200 \mathrm{~m}$ depth), shelf break $(200-\geq 1000 \mathrm{~m})$, slope $(1000-\geq 3000 \mathrm{~m})$, and oceanic $(>3000 \mathrm{~m}$ ) waters. We extracted bathymetry from ETOPO1 (Amante \& Eakins, 2009) as the average depth within a 1 arc-minute grid cell and then categorized each point into bathymetric habitats described above. Likewise, we calculated the time spent within national exclusive economic zones (EEZ; VLIZ 2014) to inform conservation and management efforts across the North Pacific.

Kernel density estimates (KDE) were computed to quantify spatial distributions of immature birds by 
sex, source colony, age class, and season. Age class was considered to be initial dispersal (summer), flight year 1, flight year 2 , and flight year $3+(3-5 \mathrm{yr})$. No tagged birds sustained flight for more than $10 \mathrm{~d}$ after fledging in May; therefore, June was considered the first full month of flight; thus, a year of flight spans from June to May. Interpolated tracks were projected using a Lambert's equal-area azimuthal projection. Then, a utilization distribution (UD) was computed for each group in 'adehabitatHR', on a $5 \times 5 \mathrm{~km}$ grid with a bivariate normal kernel (Worton 1995, Calenge 2006). We chose a smoothing parameter of $50 \mathrm{~km}(\mathrm{~h})$, as this is roughly equivalent to the average distance traveled between GPS fixes. Due to unequal sample sizes of individuals across time, we chose to apply a consistent smoothing parameter, rather than adjust with each comparison. We calculated the utilization distribution overlap index (UDOI) for the $50 \%$ UD representing the core area of distribution and 95\% UD representing the range (Ostfeld 1986, Fieberg \& Kochanny 2005, Suryan et al. 2007). This index equals 0 when there is no overlap, 1 for complete overlap of uniform distributions, and values $<1$ indicate less overlap, while values $>1$ indicate more overlap relative to uniform space use (Fieberg \& Kochanny 2005).

The influence of the number of individuals tracked on the area of KDE estimates at the core and range scales of the source colonies was assessed using a randomization approach (Hindell et al. 2003). We constrained this analysis to the first 2 flight years. Since individuals were not tracked for the same amount of time, a sample unit was considered to be a unique individual, month, and year combination. KDE and associated areas were calculated across the range of sample units for 10 iterations to assess differences in area use between source colonies and sexes.

Since the same individuals were tracked across multiple years, we calculated the UDOI between consecutive years, to assess individual fidelity to core and range areas and compared these to the UDOI of random pairings of the same year combinations (Breed et al. 2006). In addition, we calculated the nearest-neighbor distance from daily averaged locations in flight year 2 versus flight year 1 and so on, to quantify spatial fidelity and exploratory movements. We classed daily locations based on their nearestneighbor distance as site faithful versus exploration at increasing distances (Orben et al. 2015). This was repeated for randomly paired tracks to assess whether individual spatial fidelity was higher than what might occur at random.

\section{RESULTS}

Transmitters attached via tape generated up to 8 mo of data starting in late May (Table 1). Harnessed birds provided location data for up to 5 yr (Table 1), with 5 birds tracked into their third year, 3 birds into the fourth year, and 1 bird into its fifth year (the GPS failing after $1750 \mathrm{~d}$ ). This was the only instance of the GPS receiver failing before transmissions ceased. Our primary concern was minimizing the mass of the tag and burden to the animal; therefore, the tags were not modified for marine use. Thus, the prolonged tracking periods were far beyond our initial expectations. We did, however, lose contact with 3 transmitters that ceased earlier (after 23-40 d) than the other transmitters attached with tape, which began, presumably, falling off at 60-90 d. Likewise, transmitters from 2 birds fitted with harnesses ceased transmitting in the first summer (after 43 and $83 \mathrm{~d}$ ). We do not know whether the premature cessation of signals was caused by transmitter loss, transmitter failure, or bird mortality, although 1 of these 5 individuals was resighted back on colony in subsequent years. Tracks occasionally had gaps $>24 \mathrm{~h}$ between locations ( $3.8 \pm 7.5 \mathrm{~d}$, maximum $=105 \mathrm{~d}, \mathrm{n}=646$, with 11 birds having gaps $>2 \mathrm{wk}$ ).

\section{Dispersal and movements}

Fledgling short-tailed albatross were an average of $587 \pm 161 \mathrm{~km}$ away from their source colonies when

Table 1. Duration of deployment and data obtained from satellite transmitters attached to fledgling short-tailed albatrosses Phoebastria albatrus via harness or tape. The number of locations is presented by season, where summer starts in the first flight year: June-August; fall: September-November, winter: December-February; spring: March-May

\begin{tabular}{|c|c|c|c|c|c|c|c|c|c|c|}
\hline $\begin{array}{l}\text { Attachment } \\
\text { method }\end{array}$ & Birds & $\begin{array}{l}\text { Locations } \\
\mathrm{d}^{-1} \pm \mathrm{SD}\end{array}$ & Min. & $\begin{array}{l}\text { Duration (d) } \\
\text { Max. }\end{array}$ & Mean \pm SD & $\begin{array}{c}\text { Total } \\
\text { locations }\end{array}$ & Summer & Fall & Winter & Spring \\
\hline Tape & 36 & $5.3 \pm 1.1$ & 22.8 & 252.9 & $111 \pm 45.7$ & 21711 & 16837 & 4677 & 90 & 107 \\
\hline Harness & 15 & $4.6 \pm 1.5$ & 42.9 & 1750 & $726 \pm 488$ & 42237 & 15250 & 10010 & 6881 & 10096 \\
\hline
\end{tabular}


they began sustained flight. Then for $15 \mathrm{~d}$, they dispersed to the northeast $\left(41 \pm 0.63^{\circ} ;\right.$ Fig. 1$)$. There was no difference between sexes, or transmitter attachment method, but bearings differed between colonies, with Mukojima birds moving in more northerly directions $\left(31 \pm 0.73^{\circ}, F_{1,51}=4.212, \mathrm{p}=0.045\right)$ than birds from Torishima $\left(51 \pm 0.45^{\circ}\right)$. At the end of June, Mukojima birds were significantly more to the north of their colony $\left(33 \pm 0.33^{\circ}, F_{1,47}=8.193, \mathrm{p}=0.006\right)$ than birds from Torishima $\left(45.9 \pm 0.21^{\circ}\right)$ were to theirs. This difference became non-significant $(p>$ 0.05 ) by the end of July (all birds, $40.32 \pm 0.3^{\circ}, \mathrm{n}=45$ ) and in August (all birds, $41.45 \pm 0.22^{\circ}, \mathrm{n}=37$ ) . Monthly path sinuosity for the first summer did not differ by month, colony, or sex $(p>0.05,0.415 \pm$ $0.315)$. For the first 10 flight days, birds from Torishima traveled farther each day $(262 \pm 112 \mathrm{~km}$, $\left.F_{1,51}=11.670, \mathrm{p}=0.001\right)$ than those from Mukojima $(172 \pm 71 \mathrm{~km})$. This difference was maintained through the first fall, but disappeared with time (Table 2).

In their first summer, $81 \%$ of birds that were tracked through August went to the Bering Sea; this did not differ between sexes or colonies $(p>0.05)$.
Overall $21 \%$ of birds entered the Sea of Okhotsk in their first flight year (including both transmitter attachment types); the proportion of birds from the 2 source colonies that made this foray did not differ between source colony - Torishima: 0.15, Mukojima: $0.26, \chi_{1,53}^{2}=0.369, \mathrm{p}=0.54$ ) or sex (female: 0.18 ; male: $0.24 ; \chi_{1,53}^{2}=0.028, \mathrm{p}=0.866$. Of the birds tracked from May to January during the first flight year $(\mathrm{n}=13$; primarily birds wearing harnessattached tags), $85 \%$ visited the Canadian EEZ and $69 \%$ visited the EEZ off the US west coast. Daily travel distances varied seasonally and were highest in winter and spring, and lowest in summer; birds traveled longer distances each day once they reached their third flight year (Table 2).

Immature short-tailed albatross spent the majority of their time in national waters $(83 \%)$, visiting the EEZs of 5 countries (Table 3). Most of this time was spent within Alaskan (39\%) and Russian waters $(32 \%)$; however, across seasons, birds maintained a constant presence in Alaskan waters, while occupancy of Russian waters was highest in the summer and fall (Table 3). The closest that any of the fledglings came to the Senkaku Islands was when a

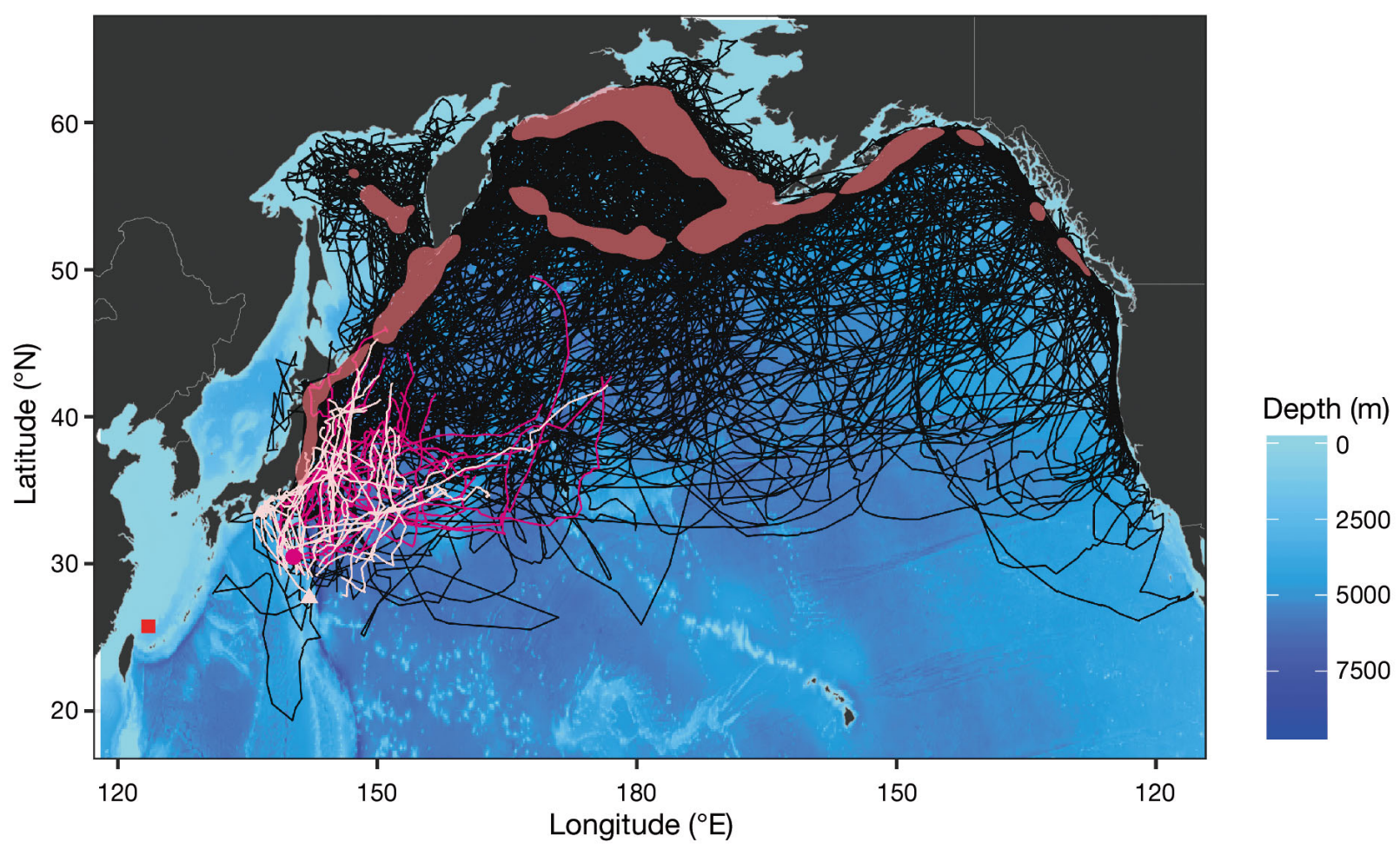

Fig. 1. At-sea tracks of immature short-tailed albatross Phoebastria albatrus after fledging from Torishima and Mukojima overlaid with the $50 \%$ utilization distribution (pink) indicating core areas of use for all birds tracked in this study up to age 5 . Torishima is indicated by a dark pink circle and Mukojima by a light pink triangle, and tracks from the first 10 flight days of birds originating at each colony are shown in the respective color to highlight initial dispersal behavior. The short-tailed albatross colony on the Senkaku Islands is denoted by a red square. Kernel densities were calculated on a $5 \times 5 \mathrm{~km}$ grid with a $50 \mathrm{~km}$ smoothing factor and a Gaussian kernel 
Table 2. Restricted maximum likelihood linear mixed model results for shorttailed albatross Phoebastria albatrus travel distance $\left(\mathrm{km} \mathrm{d}^{-1}\right)$ as a function of source colony, flight year, sex, and season factors. Bird ID was used as the random effect. Interactions were not tested. An ANOVA F-test was used to determine $p$-values for individual factors. Seasons were defined as: summer: June-August; fall: September-November; winter: December-February; spring: March-May. Values in bold indicate significance at $\mathrm{p}<0.05$

\begin{tabular}{|c|c|c|c|c|c|}
\hline Factor & Levels & $\begin{array}{c}\text { Daily distance } \\
\text { traveled }\left(\mathrm{km} \mathrm{d}^{-1}\right) \pm \mathrm{SE}\end{array}$ & $F$-value & $\mathrm{p}$-value & Bird $n$ \\
\hline \multicolumn{6}{|c|}{ Attachment: tape and harness (flight year 1 , June-November) } \\
\hline \multirow{2}{*}{$\begin{array}{l}\text { Source } \\
\text { colony }\end{array}$} & Torishima & $208.5 \pm 8$ & 9.245 & 0.0038 & 25 \\
\hline & Mukojima & $177.2 \pm 7.4$ & & & 27 \\
\hline \multirow[t]{2}{*}{ Sex } & Male & $183.9 \pm 6.9$ & 1.174 & 0.2838 & 29 \\
\hline & Female & $201.5 \pm 8.7$ & & & 23 \\
\hline \multirow[t]{2}{*}{ Season } & Summer & $172.2 \pm 4.9$ & 28.164 & $<0.0001$ & 52 \\
\hline & Fall & $235.2 \pm 12.4$ & & & 33 \\
\hline \multicolumn{6}{|c|}{ Attachment: harness (flight year 1 and flight year 2) } \\
\hline \multirow{2}{*}{$\begin{array}{l}\text { Source } \\
\text { colony }\end{array}$} & Torishima & $273 \pm 11.7$ & 0.2356 & 0.6361 & 8 \\
\hline & Mukojima & $258.4 \pm 13.0$ & & & 7 \\
\hline \multirow[t]{2}{*}{ Sex } & Male & $250.1 \pm 12.7$ & 0.3988 & 0.5396 & 6 \\
\hline & Female & $278.8 \pm 11.9$ & & & 9 \\
\hline \multirow[t]{4}{*}{ Season } & Summer & $152.4 \pm 7.5$ & 64.6923 & $<0.0001$ & 15 \\
\hline & Fall & $277.5 \pm 15.1$ & & & 12 \\
\hline & Winter & $373.3 \pm 20.9$ & & & 12 \\
\hline & Spring & $300.1 \pm 13.1$ & & & 12 \\
\hline \multicolumn{6}{|c|}{ Attachment: harness } \\
\hline \multirow[t]{3}{*}{ Flight year } & 1 & $271.2 \pm 10.4$ & 0.015 & 0.9037 & 15 \\
\hline & 2 & $259.7 \pm 14.9$ & & & 10 \\
\hline & $3+$ & $383.5 \pm 43.8$ & & & 7 \\
\hline
\end{tabular}

female third-flight-year bird from Torishima came within $774 \mathrm{~km}$ on 2 February 2014 (Fig. 1).

\section{Seasonal and ontogenetic changes}

In summer, core distributions of first- and secondyear birds were concentrated in the Kuril Islands, Sea of Okhotsk, and Bering Sea (Fig. 2). In autumn, birds moved north within the Bering Sea and east along the Aleutian Islands, and in winter, birds moved out of the northern Bering Sea and portions of the western subarctic. The winter range of birds was the greatest; some birds remained near the Aleutian Islands and southeast Bering Sea, others traveled south along the North American west coast, while others returned to Japan and the Kuril Islands. In spring, birds moved north to the Gulf of Alaska and eastern Aleutians, and some returned to the western Pacific and the vicinity of their home colonies (Supplement 1: Track animation at www.int-res.com/articles/suppl/n035 p023_supp/).

As birds aged, distributions became more constricted. Core areas of harnessed birds were $16 \%$ smaller in year $2(n=10)$ than year $1(n=15)$ and $46 \%$ smaller in year $3+$ (individual $n=$ 7 , tracks $=13$ ) than year 1 . Core areas in the Gulf of Alaska were negligible in year 3+, and though in general core areas were small along the US west coast, they were smaller and farther north for birds in their third plus year (Fig. 3). Overlap between year 1 and year 2 was high for ranges (95\% UD, 1.84 UDOI); however, UDOI indicated low overlap for core areas (50\% UD, 0.15 UDOI). Overlap between year 2 and year 3+ was high for ranges (95\% UD, 2.31 UDOI), while UDOI indicated low overlap for core areas (0.18 UDOI). This was also the case for the $50 \%$

Table 3. Percent of time immature short-tailed albatrosses Phoebastria albatrus spent within exclusive economic zones of Pacific Rim nations and in international waters

\begin{tabular}{|c|c|c|c|c|c|c|c|c|c|}
\hline \multirow{3}{*}{ Waters } & \multirow{3}{*}{$\begin{array}{c}\text { Area/ } \\
\text { country }\end{array}$} & \multirow{3}{*}{\multicolumn{2}{|c|}{$\begin{array}{cc} & \text { Flight year } \\
1 \text { (summer) } & 1\end{array}$}} & \multicolumn{3}{|c|}{ - Percent time } & \multirow{2}{*}{\multicolumn{2}{|c|}{ - All years }} & \multirow[b]{3}{*}{ Spring } \\
\hline & & & & & - & & & & \\
\hline & & & & 2 & $3+$ & Summer & Fall & Winter & \\
\hline \multirow[t]{2}{*}{ International } & Bering Sea & 1.0 & 1.1 & 0.6 & 0.9 & 0.9 & 1.6 & 0.2 & 0.9 \\
\hline & Other & 14.7 & 17.5 & 16.3 & 11.7 & 13.3 & 6.1 & 33.6 & 26.6 \\
\hline \multirow[t]{7}{*}{ National } & Japan & 6.4 & 5.4 & 8.4 & 8.9 & 6.5 & 1.2 & 8.8 & 15.9 \\
\hline & Russia & 42.5 & 30.5 & 34.1 & 37.1 & 42.7 & 39.9 & 4.6 & 13.8 \\
\hline & US Alaska & 35.4 & 40.6 & 34.7 & 40.1 & 36.6 & 48.9 & 33.5 & 35.6 \\
\hline & Canada & 0.002 & 2.6 & 2.9 & 1.2 & 0.03 & 1.6 & 8.9 & 5.1 \\
\hline & US west coast & 0 & 2.2 & 2.8 & 0.4 & 0.014 & 0.8 & 11.0 & 2.2 \\
\hline & Mexico & 0 & 0 & 0.2 & 0 & 0 & 0 & 0 & 0 \\
\hline & US Hawaii & 0 & 0 & 0 & 0.06 & 0 & 0 & 0.08 & 0 \\
\hline
\end{tabular}



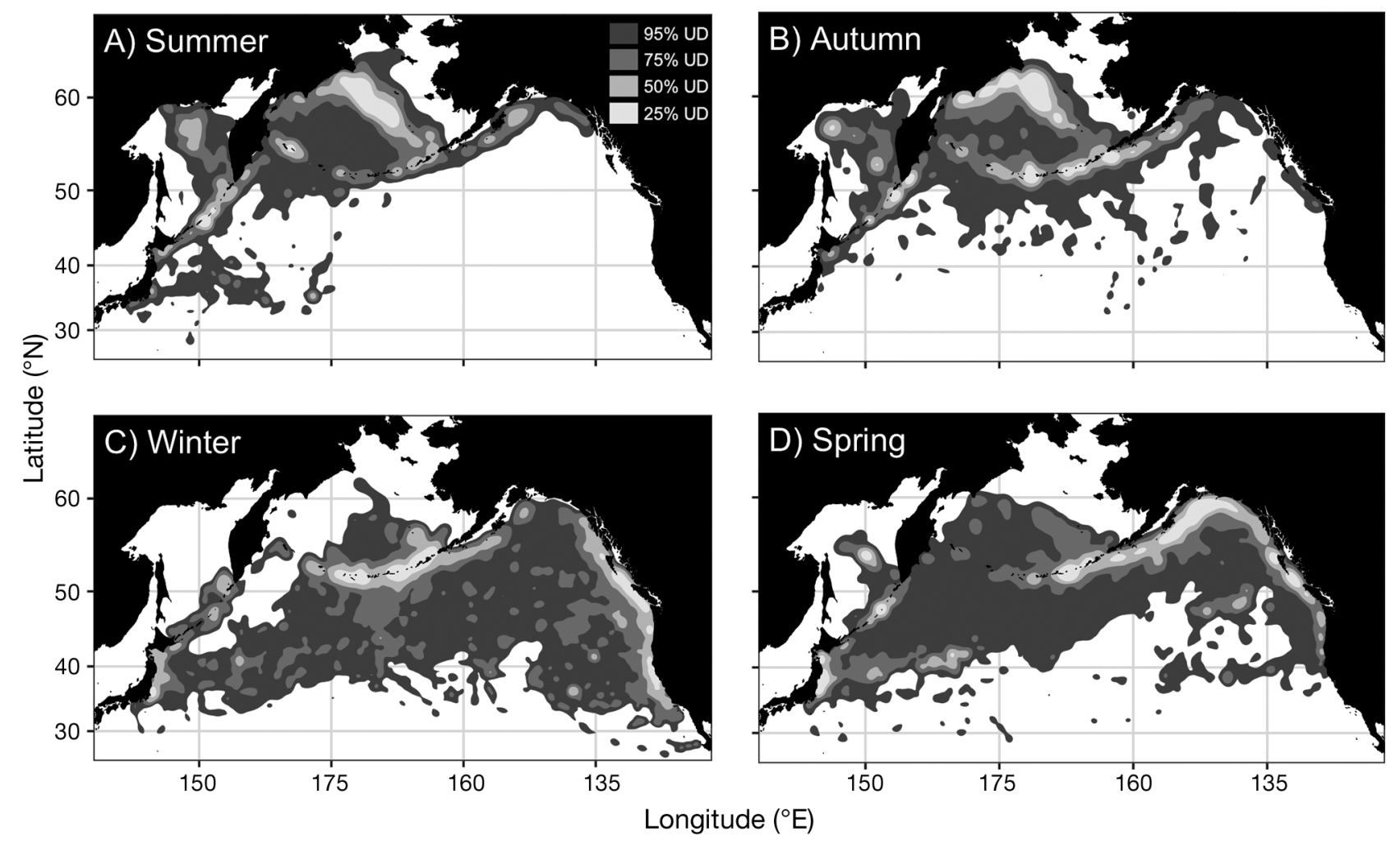

Fig. 2. Seasonal distribution of short-tailed albatrosses Phoebastria albatrus during their first 2 years of flight for (A) summer ( $\mathrm{n}=15$ birds, June-August), (B) autumn ( $\mathrm{n}=13$, September-November), (C) winter ( $\mathrm{n}=13$, December-February), and (D) spring $(\mathrm{n}=13$, March-May). The contours shown (from darkest to lightest) are the $95 \%$ utilization distribution (UD), $75 \%$ UD, $50 \%$ UD, and $25 \%$ UD. Kernel densities were calculated on a $5 \mathrm{~km}$ grid with a $50 \mathrm{~km}$ smoothing factor and a Gaussian kernel. Only birds with transmitters attached by harness are included

UDOI between years 1 and $3+(0.101$ UDOI) and for the $95 \%$ UDOI (1.84 UDOI). Proportion of time spent in bathymetric domains shifted as fledglings aged except for shelf habitat $\left(F_{1,30}=0.1457, \mathrm{p}=0.705\right)$ (Fig. 4). In their first flight year, birds used oceanic domains more than birds in year $3+(p=0.01)$, while use of shelf-break and slope habitats was significantly lower in the first year than the third plus year $(p<0.05)$, with intermediate levels seen in the second flight year (Fig. 4).

\section{Sexes and source colonies}

Males and females exhibited high overlap in overall ranges (2.27 UDOI); however, the UDOI of core areas suggests low overlap (0.23 UDOI). This pattern continued into the first 2 flight years (Fig. 3). Though there are subtle differences in location, the $50 \%$ UDs, the UDs for both males and females are limited to the continental margins, shelf-break regions, and the Sea of Okhotsk. We found no significant differences in daily travel distances between the sexes across all age classes (Table 2), or use of bathymetric domains during the first 6 mo post-fledgling $\left(F_{4,202}=0.019, \mathrm{p}=\right.$ 0.776, Fig. 4). All birds tracked for complete subsequent years returned to the western Pacific in flight year 2; only 2 birds returned to close proximity to the colonies. Both were females and returned to their respective source colonies; one from Torishima returned in late winter of her second year and one from Mukojima returned in early spring of her third year. The female from Torishima also flew close to Mukojima during the winter of her third year.

The source colony had minor influences on at-sea distribution. In the first summer, Torishima birds and Mukojima birds exhibited high overlap in ranges (1.18 UDOI), but low overlap in core areas (0.11 UDOI), similar to the overlap seen between sexes. Overall, overlap declined as birds aged, except for the UDOI of the $50 \%$ UD, which was similarly low between years 2 and 3 (Table 4). Bathymetric domains used by Torishima and Mukojima birds within the first 6 mo of flight were not significantly different $\left(F_{1,99}=0.1406, \mathrm{p}=0.7081\right.$, Fig. 4). In the first 2 flight years, birds from Mukojima occupied more 

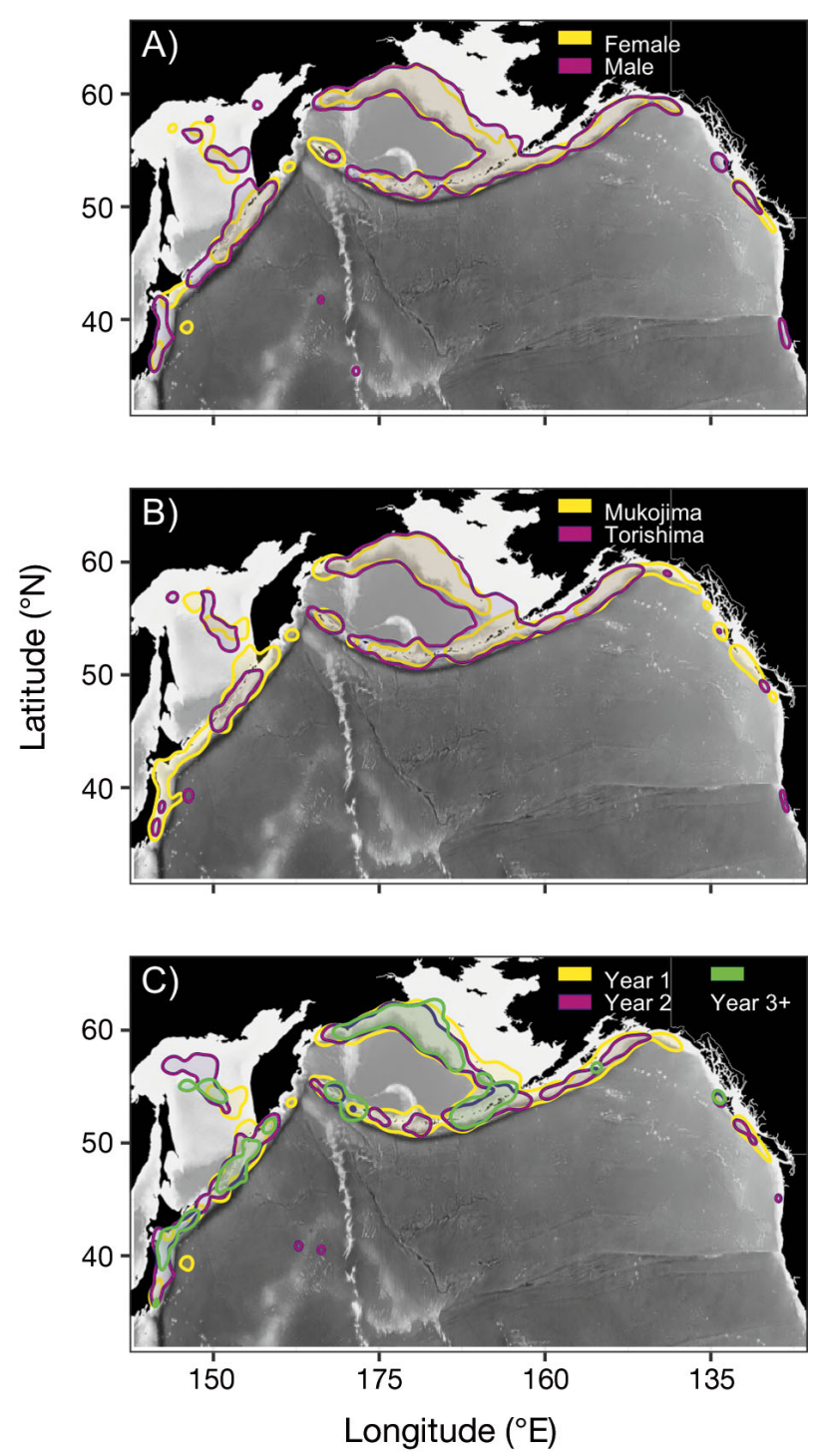

Fig. 3. Core areas (50\% utilization distribution) of fledgling short-tailed albatrosses Phoebastria albatrus from their first 2 years of flight for (A) sexes (male $=29$ [yellow], female $=$ 24 [purple]), (B) source colonies (Mukojima $=27$ [yellow], Torishima $=26$ [purple]), and $(\mathrm{C})$ flight years (year $1=15$ [yellow], year $2=10$ [purple], year $3+=7$ [green]). Kernel densities were calculated on a $5 \times 5 \mathrm{~km}$ grid with a $50 \mathrm{~km}$ smoothing factor and a Gaussian kernel. Only birds with transmitters attached by harness are included

expansive core areas; however, 3 Torishima colony birds traveled farther south along the US west coast (Fig. 3, Fig. S1 (area estimates) in Supplement 2 at www.int-res.com/articles/suppl/n035p023_supp/). Though the contours varied, core areas of both colonies were concentrated along the continental shelves of the North Pacific and the Sea of Okhotsk, and none occurred in the deep waters of the North Pacific basin (Fig. 2).

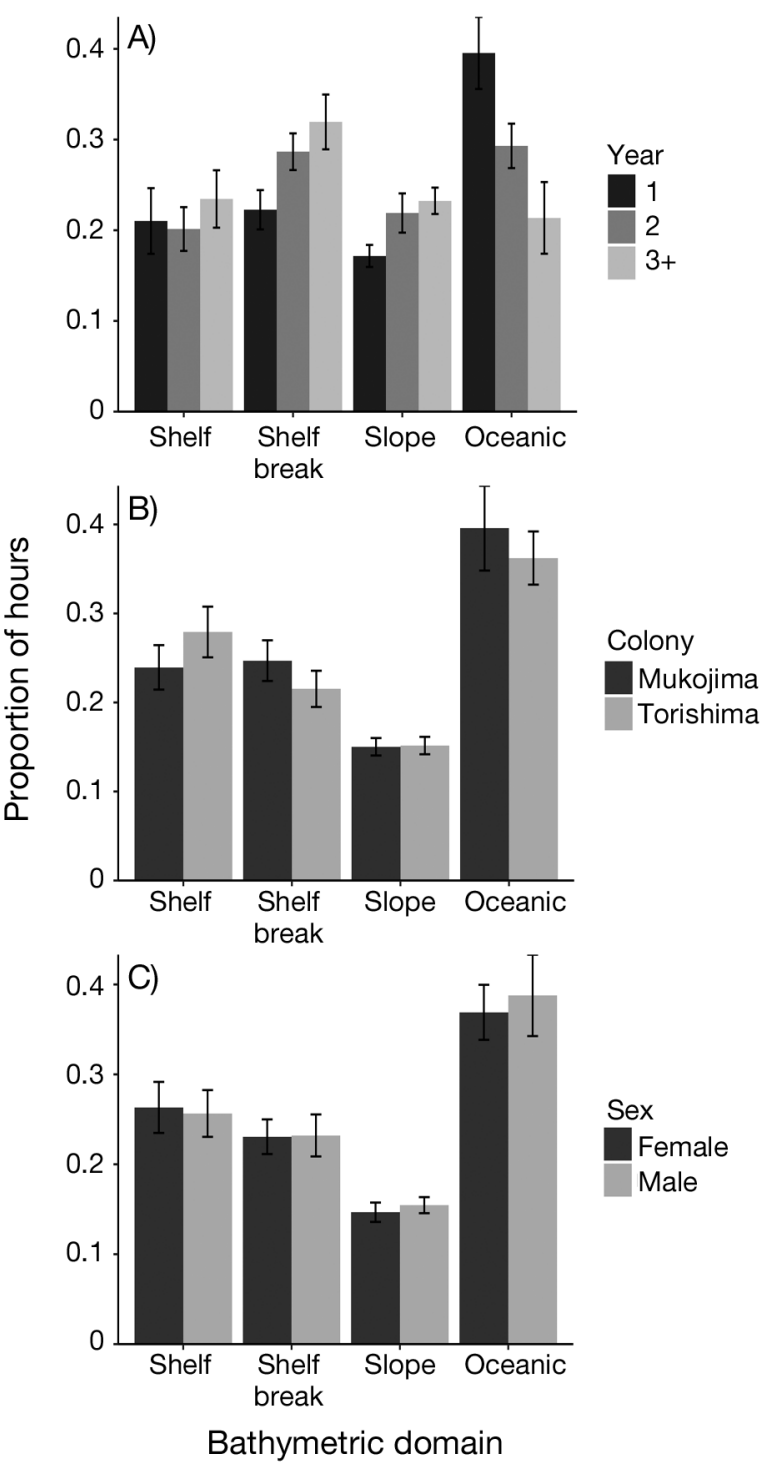

Fig. 4. Proportion of hours $( \pm \mathrm{SE})$ spent by short-tailed albatrosses Phoebastria albatrus in continental shelf $(<200 \mathrm{~m}$ depth), shelf break (200-1000 m), slope (1000-3000 m) and oceanic bathymetric (>3000 m) domains for (A) first-, second-, and third-plus-flight-year birds shown in consecutively light shades of grey ( $\mathrm{n}=15$, birds carrying harnessattached transmitters only), and for all birds during their first 6 mo of flight $(n=53)$ for $(B)$ Mukojima and Torishima birds, and $(\mathrm{C})$ females and males

\section{Individual fidelity}

Nine individuals were tracked through multiple years, resulting in 15 consecutive year pairs (Fig. S2 (individual tracks) in Supplement 2). Notably, through year 3, one female visited the Sea of Okhotsk every year and never visited the Bering Sea shelf break, though all other individuals tracked for full years did. Three individuals foraged in the Sea of 
Table 4. Summary of utilization distribution overlap indices (UDOI) for short-tailed albatrosses Phoebastria albatrus between sexes and source colonies during the initial flight years. Individuals are repeated through the years with 15 tracks comprising the 3+ flight year category. Distributions for each full year are biased towards the beginning of the year as all available data were included; however, only the birds with harnessed-attached loggers were included in the full flight-year-group comparisons

\begin{tabular}{|lcccc|}
\hline & $\begin{array}{c}\text { Flight } \\
\text { year 1 } \\
\text { (summer) }\end{array}$ & Flight & Flight & Flight \\
& year 2 & year 3+ \\
\hline Sexes & & & & \\
n (Male: Female) & $29: 24$ & $6: 9$ & $4: 6$ & $4: 3$ \\
50\% UDOI & 0.110 & 0.189 & 0.102 & 0.041 \\
95\% UDOI & 1.220 & 1.926 & 1.701 & 1.120 \\
Source colony & & & & \\
n (Torishima: Mukojima) & $26: 27$ & $7: 8$ & $6: 4$ & $3: 4$ \\
50\% UDOI & 0.101 & 0.183 & 0.060 & 0.073 \\
95\% UDOI & 1.178 & 1.880 & 1.613 & 1.598 \\
\hline
\end{tabular}

Okhotsk during their first year, and 2 returned there in year 2, while 1 individual entered the Sea of Okhotsk first during its second flight year and returned in its third. From year 1 to year 2, individual UDOI $(\mathrm{n}=9)$ of core and range distributions were $0.04 \pm 0.04(50 \% \mathrm{UD})$ and $0.61 \pm 0.27(95 \% \mathrm{UD})$. In comparison, randomly paired individuals showed less overlap for range distributions $(0.38 \pm 0.29, \mathrm{n}=36)$ and similarly low levels of overlap for the $50 \%$ UD $(0.02 \pm 0.03)$. Between year 2 and 3 , individuals had a higher than normal overlap between range areas $(1.24 \pm 0.4, \mathrm{n}=5)$, and again low overlap between
$50 \%$ UDs $(0.09 \pm 0.05)$. Randomly paired year 2 and 3 distributions had lower similarity for the $95 \%$ UD $(0.45 \pm 0.42, \mathrm{n}=18)$ and $50 \%$ UDs $(0.02 \pm 0.03)$. Only 1 individual was tracked for a full fourth flight year and this bird appeared to be more site faithful than average (year 1:2 50\% UDOI $=0.11$; year 2:3 $=0.17$; year $3: 4=0.19$ ).

Compared with year 1, year 2 birds did not exhibit site fidelity more than might occur by chance, as indicated by complete overlap of the standard deviation of the nearest-neighbor curves (Fig. 5). Third-flightyear birds returned to locations within $20 \mathrm{~km}$ of where they visited previously (in year 1 and 2) more frequently than might be expected at random, though this effect declined at larger scales (Fig. 5). At the scale of $20 \mathrm{~km}$, individuals continued to explore new areas as they aged (year 2: $86 \pm 7 \%$; year 3: $65 \pm$ $6 \%$; year 4:52\% new spatial territory).

\section{DISCUSSION}

During their initial flight years, juvenile shorttailed albatrosses used an impressive portion of the North Pacific from tropical to arctic waters, including the transition zone, California Current system, subarctic gyres, and the marginal seas: the Bering Sea and Sea of Okhotsk. Within this expansive range, birds were remarkably consistent in their preference for productive shelf breaks and continental margins, reflected by the core areas of their distributions. We did find some initial differences in movement pat-

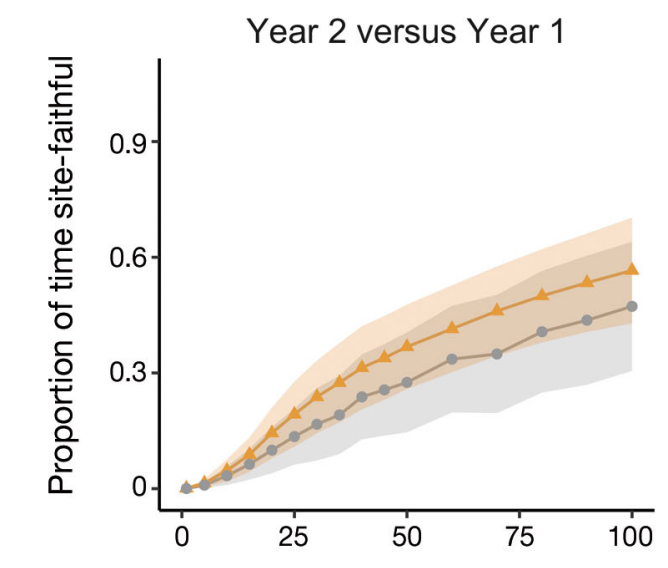

\section{Year 3 versus Year $1 \& 2$}

Year 4 versus Year 1, 2, \& 3


Fig. 5. Proportion of time immature short-tailed albatross Phoebastria albatrus spent returning to regions visited in prior years within an increasing spatial scale (threshold between site-faithful and exploratory movements). The orange line (triangles) is the result of comparing individual birds with their previous year(s) tracks, while the grey line (circles) was calculated by comparing tracks with randomly selected tracks of the same year combinations. Shaded areas represent SD. Only 1 bird was tracked for a complete fourth flight year 
terns of naturally reared and translocated fledglings; however, these did not lead to fundamental differences in bathymetric habitat use or distributions. Seasonally, juvenile short-tailed albatrosses were more widely dispersed and traveled more during the winter. Use of the Bering Sea shelf primarily occurred in summer and autumn, while the Aleutian Island chain was occupied year round. As birds aged, habitat use switched away from pelagic regions to shelf break and slope habitats, becoming more similar to adult distributions (Suryan et al. 2006, Suryan \& Fischer 2010).

Individual immature short-tailed albatrosses have a broad spatial range, considerably larger than previously shown (Suryan et al. 2006, Suryan \& Fischer 2010). Immatures had high use of the Sea of Okhotsk in contrast to adult-tracking studies (Suryan et al. 2007). The Sea of Okhotsk is part of the historical range (Hasegawa \& DeGange 1982), and more recently in 2002, one 6-mo-old bird was caught as commercial fisheries bycatch in the region (USFWS 2014). In the late 1800 s, short-tailed albatrosses were abundant in the Bering Strait region, and around St. Lawrence Island in the summer (Nelson et al. 1887). These areas were visited by immature short-tailed albatrosses in this study. This is in contrast to few recent at-sea sightings and no use by previously tracked short-tailed albatrosses (Piatt et al. 2006, Suryan et al. 2006, Suryan \& Fischer 2010, Kuletz et al. 2014). Use of the western coast of North America was common, and coincided with previous tracking studies and at-sea observations (Suryan et al. 2006, Guy et al. 2013), except in the southern California Current as tracked juveniles ranged into the region near Point Conception. In addition, one bird entered the Mexican EEZ near Baja. Perhaps these southerly excursions are not surprising given that short-tailed albatrosses were regularly seen in Mexican waters prior to 1900, and in more recent years a few individuals have been seen (Grinnell 1928, Santaella \& Sada 1991). In the western Pacific, 1 bird entered the Sea of Japan, through Tsugaru Strait and 1 bird traveled as far south as $19.4^{\circ} \mathrm{N}$ into the tropical Philippine Sea, but were generally limited in this portion of the former range (Hasegawa \& DeGange 1982).

Within their more expansive ranges, the core areas of immature albatrosses overlapped with many of the key foraging areas identified in previous studies of adult short-tailed albatrosses: near the Kuril Islands, the Bering Sea outer shelf and slope region, and Aleutian Islands (Piatt et al. 2006, Suryan et al. 2006). The population size of short-tailed albatrosses is increasing but is several orders of magnitude smaller than it used to be; therefore, it is likely that our observations of immature short-tailed albatrosses in the Sea of Okhotsk, Gulf of Alaska, and western coast of North America constitute reoccupation of historical foraging areas. It is uncertain, however, why immature birds occupy regions not typically used by adults. Such differences in distribution could be driven by innate differences in the foraging capacity, aerodynamic performance between immatures and adults (Shaffer et al. 2001a, Suryan et al. 2008), or by timing and energetic constraints (e.g. molt, recovery from reproduction) faced by annually breeding birds that prevent them from visiting more distant seasonally productive regions (e.g. California Current and Gulf of Alaska). Regardless, the movement patterns documented by the present study highlight the impressive capacity of immature short-tailed albatrosses to cross and explore the majority of the North Pacific.

Unlike immature and adult short-tailed albatrosses, other studies examining post-fledgling distributions of other albatross species have identified relatively low overlap between immatures and adults (Weimerskirch et al. 2006, Alderman et al. 2010, Gutowsky et al. 2014a). Initially, fledgling shorttailed albatrosses departed from their colonies with more varied and oceanic trajectories than previously tracked adults from Torishima who tended to follow the coast of Japan north to the Kuril Islands before either continuing along the continental margins or traveling offshore to make the crossing to the Aleutians (Suryan et al. 2006). At a larger scale, both juveniles and adults departed their colonies with similar flight orientation, suggesting juveniles have an innate ability to orientate, similar to what was found for a number of other procellariforms (de Grissac et al. 2016). Despite initial variability, the majority of fledgling birds arrived in the Bering Sea that first summer where their distributions overlapped with adults. This is in contrast to other albatrosses where segregation between adult and immatures has been observed. For instance, juvenile wandering albatross Diomedea exulans foraged in less-productive subtropical waters where adults did not, possibly the result of competitive avoidance by juveniles and functional preference for wind speeds (Weimerskirch et al. 2006). Segregation is even the case for shy albatrosses, where both adults and juveniles forage almost exclusively in Bass Strait and Southern Australian waters, yet show little overlap of core foraging areas (Alderman et al. 2010). It is also the case for fledgling black-footed albatrosses $(<3 \mathrm{mo})$ who forage in subtropical waters, while adults prefer shelfbreak habitats in the North Pacific (Fischer et al. 
2009, Gutowsky et al. 2014a). At present, competitive exclusion of preferred foraging areas by adult shorttailed albatrosses seems unlikely. However, competition likely occurred historically and, as population numbers increase, may become an important factor in shaping immature distributions. Density-driven processes seem likely to affect immature albatrosses, as, for example, survival of juvenile wandering albatrosses is related to population size (Fay et al. 2015).

The individual variation in departure headings of fledglings leaving the 2 source colonies suggests that at the small and immediate scale, fledgling albatrosses are relying on in situ cues when making their first excursion from the colony. Yet, the apparent large-scale similarities between fledgling dispersal and adults (discussed in the previous paragraph), suggest innate orientation abilities. Often translocations are used to study the innate navigation capacity of animals (Thorup \& Holland 2009), and though we only moved fledglings $350 \mathrm{~km}$, we found that birds from Mukojima had significantly different and more northerly paths than those from Torishima, suggesting that the translocated albatrosses were able to adjust to their new departure location. This is in contrast to some terrestrial bird species, such as juvenile sparrows, that need to learn their navigational map (Thorup et al. 2007). However, orientation was not absolute as there were a few albatross fledglings that went directly to the US west coast and 1 bird that never visited the Bering Sea shelf region in $3 \mathrm{yr}$, providing evidence for the ability of fledgling shorttailed albatrosses to adjust to proximate cues when choosing their destinations.

Undoubtedly, learning is a key part of the immature years for albatrosses. However, we found that immature birds tracked for 2 or more years showed only low levels of spatial fidelity. In fact, the farthest west, south, and east excursions were made by third-year birds, indicating continued exploration during these early years. At the same time, we observed shifts in habitat use towards regions favored by adults: shelf break and slope regions and a constriction of coreuse areas. After the first year, birds undergo flight feather molt; this energy expenditure and compromised flight performance could contribute to reduced core areas (Gutowsky et al. 2014b). For short-tailed albatrosses, learning may constitute recognizing favorable foraging grounds, but perhaps more importantly, young birds may need to learn to recognize profitable foraging opportunities, and discern when to land, as taking off from the water's surface is energetically expensive for albatrosses (Shaffer et al. 2001b). This may be reflected in the gradual shift of bathymetrically linked habitat preference that we observed. Previous tracking suggested that juveniles are traveling twice the distances per day that adult birds travel (Suryan et al. 2008). We found seasonal differences in daily travel distances but we did not observe an ontogenetic shift in travel distance for our birds. How much time it takes to learn equivalent foraging skills is unknown. Short-tailed albatrosses reach adult plumage at $12 \mathrm{yr}$ of age, yet recent observations indicate much younger birds are able to successfully breed (Deguchi et al. 2017), suggesting learning foraging skills adequate for reproduction can occur relatively quickly. Immature short-tailed albatrosses showed distinct seasonal changes in their distributions. Preferred prey is generally unknown, but it seems reasonable to suggest that the once highly abundant short-tailed albatross is a generalist predator and scavenger and shifts prey species across its range (Tickell 2000). Indeed, we saw little evidence that immature birds were developing regional preferences. The Aleutian Island chain, from Unimak Pass in the east to Seguam Pass in the west, marked one region with consistent year-round occupancy by immature short-tailed albatrosses. Likewise, the passes through the Kuril Island chain showed similar consistent occupancy. The eastern Aleutians are notable for high diversity and yearround densities of seabirds, particularly Unimak Pass (Renner et al. 2008). Seguam Pass is a noted hotspot for short-tailed albatrosses (Piatt et al. 2006). These passes provide predictable areas of strong tidal mixing and frontal zones that enhance foraging opportunities for surface-foraging seabirds, such as the short-tailed albatross (Jahncke et al. 2005, Ladd et al. 2005). Presumably, seasonal shifts in distributions were influenced by changes in prey availability, as is often the case for highly mobile marine predators (Block et al. 2011). During the winter, when prey may be less predictable across the North Pacific, birds traveled more each day and distributions shifted southward. Most birds visited the California Current during this time, though short-tailed albatrosses are seen in this region year round (Guy et al. 2013). The Gulf of Alaska was visited at high densities in the spring. Finally, the northernmost portion of their range, the Bering Sea, was favored in the summer and fall, when prey resources along the shelf break are known to be abundant (Springer et al. 1996). This seasonal shift in distributions could also indicate a reliance on or preference for daytime foraging strategies by immature individuals. Like Hawaiian albatrosses (Conners et al. 2015), adult short-tailed albatrosses may forage at night (Suryan et al. 2007); 
however, the extent to which this is region specific or important for immature birds is currently unknown.

In addition to prey resources, needs such as nest site and mate prospecting likely influence returning to breeding colonies, and thus influence seasonal distributions. Like adult females (Suryan et al. 2007), immature females may be remaining longer in the western Pacific. We saw some evidence of this as only females returned to the vicinity of breeding colonies, but our sample sizes were very small. Overall, we found no evidence of differences between sexes in distance traveled, space use, or bathymetric habitat preferences. This may be due to our small sample sizes, especially as birds aged, as spatial differences could be subtle due to each individual's expansive range, and/or the birds that we tracked were too young for sex-specific distribution patterns to develop. In other species of albatross, spatial segregation has been observed between breeding adults (Weimerskirch et al. 1993, Phillips et al. 2004), and attributed to size dimorphism (Shaffer et al. 2001a), but it is not known whether this is the case for adult short-tailed albatrosses. For juveniles, size dimorphism between the sexes is likely small and this could be a contributing factor as to why we found no differences between the sexes in our study.

\section{CONSERVATION IMPLICATIONS}

Translocations are difficult, in particular for colonial or migratory species, and successes are associated with multiple site- and species-specific variables (Wolf et al. 1998). Thus, changing the starting point of migration could have notable impact on distributions, as colony-level differences in non-breeding distributions are apparent for Laysan albatrosses (Young et al. 2009). Our multi-year comparison of translocated Mukojima and non-translocated Torishima short-tailed albatross shows that although core regions are dissimilarly shaped, they occupy the same large-scale habitats and regions. It is possible that at historically larger population levels, albatrosses from these colonies were segregated at sea. We did initially find that translocated Mukojima birds traveled less each day, potentially due to higher fledgling weights (Deguchi et al. 2014). However, being heavier may contribute to or indicate higher fitness (Cornioley et al. 2017). In general, for shorttailed albatross we suggest translocation has had no lingering or concerning effects on immature distributions, since individual fledglings from both colonies visited all key foraging regions and traversed the
North Pacific basin multiple times. Observations of translocated fledglings at both Torishima and Mukojima, along with successful breeding efforts of translocated birds at Mukojima, support this conclusion (Deguchi et al. 2017).

Individual immature short-tailed albatrosses explored most of the North Pacific during their initial flight years, showing an impressive ability to move and adjust to resources at an ocean basin scale. Once thought to have a population of millions of individuals (Hasegawa \& DeGange 1982), this spatial flexibility and exploratory capacity may be a key ecological trait that facilitated such a large population size and may be contributing to the faster-than-expected current population increase. Immature birds spend the majority of their time within the EEZ of Pacific Rim nations and more time in Russian waters than adult birds (Suryan et al. 2007). This implies different extents of vulnerability to specific fisheries for immature and adult birds, and continued conservation efforts are needed to protect the immature portion of the population.

As populations continue to grow, augmented by conservation efforts on land and at sea, we can expect short-tailed albatrosses to continue to recolonize historical ranges and foraging areas. Yet, no birds entered the EEZ surrounding the Senkaku Islands, where there is a colony of short-tailed albatrosses that show genetic separation from the population breeding on Torishima (Kuro-o et al. 2010). The lack of exploration of these waters and waters even farther west in the subtropical marginal seas that were formerly used by short-tailed albatrosses (Hasegawa \& DeGange 1982) suggests the potential for colony level at-sea segregation, particularly in these regions. This emphasizes the continued need for at-sea conservation efforts and identification (including genotyping, if needed) of by-caught individuals, since the seasonal patterns of spatial use of birds originating from the Senkaku Islands is unknown.

Acknowledgements. Research in this study was made possible by funding from the National Fish and Wildlife Foundation, US Fish and Wildlife Service, Japan Ministry of Environment, North Pacific Research Board, Japan Ministry of Education, Culture, Sports, Science and Technology, Suntory Fund for Bird Conservation, Asahi Newspaper Company, Mitsui \& Co., Ltd. Environmental Fund, and Oregon State University. We thank J. Graham and G. Thompson and one anonymous reviewer for providing feedback and revisions of earlier versions of this manuscript. Also, special thanks to H. Hasegawa, H. Murakami, L. Perriman, Y. Watanabe, T. Harada, T. Work, and N. Emura. This is publication no. 649 of the North Pacific Research Board. 


\section{LITERATURE CITED}

Agostinelli C, Lund U (2013) R package 'circular': circular statistics (version 0.4-7); https://r-forge.r-project.org/ projects/circular/

Alderman RL, Gales R, Hobday AJ, Candy SG (2010) Postfledging survival and dispersal of shy albatross from three breeding colonies in Tasmania. Mar Ecol Prog Ser 405:271-285

Amante C, Eakins BW (2009) ETOPO1 1 arc-minute global relief model: procedures, data sources and analysis. NOAA Tech Memo NESDIS NGDC-24. National Geophysical Data Center, NOAA

Austin OL Jr (1949) The status of Steller's albatross. Pac Sci 3:283-295

Baylis AMM, Page B, McKenzie J, Goldsworthy SD (2012) Individual foraging site fidelity in lactating New Zealand fur seals: continental shelf vs. oceanic habitats. Mar Mamm Sci 28:276-294

Block BA, Jonsen ID, Jorgensen SJ, Winship AJ and others (2011) Tracking apex marine predator movements in a dynamic ocean. Nature 475:86-90

Bolker BM, Brooks ME, Clark CJ, Geange SW, Poulsen JR, Stevens MHH, White JSS (2009) Generalized linear mixed models: a practical guide for ecology and evolution. Trends Ecol Evol 24:127-135

Breed GA, Bowen WD, McMillan JI, Leonard ML (2006) Sexual segregation of seasonal foraging habitats in a nonmigratory marine mammal. Proc R Soc B 273:2319-2326

Bregnballe T, Frederiksen M (2006) Net-entrapment of great cormorants Phalacrocorax carbo sinensis in relation to individual age and population size. Wildl Biol 12: $143-150$

Calenge C (2006) The package 'adehabitat' for the R software: a tool for the analysis of space and habitat use by animals. Ecol Modell 197:516-519

* Causey D, Corbett DG, Lefevre C, West DL, Savinetsky AB, Kiseleva NK, Khassanov BF (2005) The palaeoenvironment of humans and marine birds of the Aleutian Islands: three millennia of change. Fish Oceanogr 14: 259-276

* Conners MG, Hazen EL, Costa DP, Shaffer SA (2015) Shadowed by scale: subtle behavioral niche partitioning in two sympatric, tropical breeding albatross species. Mov Ecol 3:28

Cornioley T, Jenouvrier S, Börger L, Weimerskirch H, Ozgul A (2017) Fathers matter: male body mass affects lifehistory traits in a size-dimorphic seabird. Proc R Soc B 284:20170397

Costa DP, Breed GA, Robinson PW (2012) New insights into pelagic migrations: implications for ecology and conservation. Annu Rev Ecol Evol Syst 43:73-96

Crespin L, Harris MP, Lebreton JD, Frederiksen M, Wanless S (2006) Recruitment to a seabird population depends on environmental factors and on population size. J Anim Ecol 75:228-238

de Grissac S, Börger L, Guitteaud A, Weimerskirch H (2016) Contrasting movement strategies among juvenile albatrosses and petrels. Sci Rep 6:26103

* de Grissac S, Bartumeus F, Cox SL, Weimerskirch H (2017) Early-life foraging: behavioral responses of newly fledged albatrosses to environmental conditions. Ecol Evol 7: 6766-6778

Deguchi T, Jacobs J, Harada T, Perriman L and others (2012) Translocation and hand-rearing techniques for establish- ing a colony of threatened albatross. Bird Conserv Int 22: 66-81

* Deguchi T, Suryan RM, Ozaki K, Jacobs JF, Sato F (2014) Translocation and hand-rearing of the short-tailed albatross Phoebastria albatrus: early indicators of success for species conservation and island restoration. Oryx 48: 195-203

Deguchi T, Sato F, Eda M, Izumi H and others (2017) Translocation and hand-rearing result in short-tailed albatrosses returning to breed in the Ogasawara Islands 80 years after extirpation. Anim Conserv 20:341-349

* Fay R, Weimerskirch H, Delord K (2015) Population density and climate shape early-life survival and recruitment in a long-lived pelagic seabird. J Anim Ecol 84:1423-1433

Fayet AL, Freeman R, Shoji A, Padget O, Perrins CM, Guilford $T$ (2015) Lower foraging efficiency in immatures drives spatial segregation with breeding adults in a longlived pelagic seabird. Anim Behav 110:79-89

Fieberg J, Kochanny CO (2005) Quantifying home-range overlap: the importance of the utilization distribution. J Wildl Manage 69:1346-1359

KFinkelstein ME, Wolf S, Goldman M, Doak DF, Sievert PR, Balogh G, Hasegawa H (2010) The anatomy of a (potential) disaster: volcanoes, behavior, and population viability of the short-tailed albatross (Phoebastria albatrus). Biol Conserv 143:321-331

*Fischer KN, Suryan RM, Roby DD, Balogh GR (2009) Postbreeding season distribution of black-footed and Laysan albatrosses satellite-tagged in Alaska: inter-specific differences in spatial overlap with North Pacific fisheries. Biol Conserv 142:751-760

* Fridolfsson AK, Ellegren H (1999) A simple and universal method for molecular sexing of non-ratite birds. J Avian Biol 30:116-121

*Gianuca D, Phillips RA, Townley S, Votier SC (2017) Global patterns of sex- and age-specific variation in seabird bycatch. Biol Conserv 205:60-76

Grinnell J (1928) A distributional summation of the ornithology of Lower California. University of California Press, Berkeley, CA

Guilford T, de Perera TB (2017) An associative account of avian navigation. J Avian Biol 48:191-195

Guilford T, Freeman R, Boyle D, Dean B, Kirk H, Phillips RA, Perrins CM (2011) A dispersive migration in the Atlantic puffin and its implications for migratory navigation. PLOS ONE 6:e21336

*Gutowsky SE, Tremblay Y, Kappes MA, Flint EN and others (2014a) Divergent post-breeding distribution and habitat associations of fledgling and adult black-footed albatrosses Phoebastria nigripes in the North Pacific. Ibis 156: $60-72$

*Gutowsky SE, Gutowsky LF, Jonsen ID, Leonard ML, Naughton MB, Romano MD, Shaffer SA (2014b) Daily activity budgets reveal a quasi-flightless stage during non-breeding in Hawaiian albatrosses. Mov Ecol 2:23

Guy TJ, Jennings SL, Suryan RM, Melvin EF and others (2013) Overlap of North Pacific albatrosses with the US west coast groundfish and shrimp fisheries. Fish Res 147: 222-234

Hasegawa H, DeGange AR (1982) The short-tailed albatross, Diomedea albatrus, its status, distribution and natural history. Am Birds 36:806-814

*Hazen EL, Jorgensen S, Rykaczewski RR, Bograd SJ and others (2012a) Predicted habitat shifts of Pacific top predators in a changing climate. Nat Clim Change 3:234-238 
Hazen EL, Maxwell SM, Bailey H, Bograd SJ and others (2012b) Ontogeny in marine tagging and tracking science: technologies and data gaps. Mar Ecol Prog Ser 457: 221-240

Higuchi H, Ozaki K, Fujita G, Minton J (1996) Satellite tracking of white-naped crane migration and the importance of the Korean demilitarized zone. Conserv Biol 10: 806-812

* Higuchi H, Pierre JP, Krever V, Andronov V (2004) Using a remote technology in conservation: satellite tracking white-naped cranes in Russia and Asia. Conserv Biol 18: 136-147

Hindell MA, Bradshaw CJA, Sumner MD, Michael KJ, Burton HR (2003) Dispersal of female southern elephant seals and their prey consumption during the austral summer: relevance to management and oceanographic zones. J Appl Ecol 40:703-715

Hucke-Gaete R, Osman LP, Moreno CA, Torres DE (2004) Examining natural population growth from near extinction: the case of the Antarctic fur seal at the South Shetlands, Antarctica. Polar Biol 27:304-311

* Jahncke J, Coyle KO, Hunt GL (2005) Seabird distribution, abundance and diets in the eastern and central Aleutian Islands. Fish Oceanogr 14(Suppl 1):160-177

Jones HP, Kress SW (2012) A review of the world's active seabird restoration projects. J Wildl Manage 76:2-9

Kuletz KJ, Renner M, Labunski EA, Hunt GL Jr (2014) Changes in the distribution and abundance of albatrosses in the eastern Bering Sea: 1975-2010. Deep Sea Res II 109:282-292

Kuro-o M, Yonekawa H, Saito S, Eda M, Higuchi H, Koike H, Hasegawa H (2010) Unexpectedly high genetic diversity of mtDNA control region through severe bottleneck in vulnerable albatross Phoebastria albatrus. Conserv Genet 11:127-137

Ladd C, Jahncke J, Hunt GL Jr, Coyle KO, Stabeno PJ (2005) Hydrographic features and seabird foraging in Aleutian Passes. Fish Oceanogr 14:178-195

Le Boeuf BJ, Condit R, Morris PA, Reiter J (2011) The northern elephant seal (Mirounga angustirostris) rookery at Año Nuevo: a case study in colonization. Aquat Mamm 37:486-501

McConnell BJ, Chambers C, Fedak MA (1992) Foraging ecology of southern elephant seals in relation to the bathymetry and productivity of the Southern Ocean. Antarct Sci 4:393-398

McConnell BJ, Fedak MA, Burton HR, Engelhard GH, Reijnders PJH (2002) Movements and foraging areas of naïve, recently weaned southern elephant seal pups. J Anim Ecol 71:65-78

Murray TE, Bartle JA, Kalish SR (1993) Incidental capture of seabirds by Japanese southern bluefin tuna longline vessels in New Zealand waters, 1988-1992. Bird Conserv Int 3:181-210

Nelson EW, True FW, Bean TH, Edwards WH (1887) Report upon natural history collections made in Alaska: between the years 1877 and 1881. Government Printing Office, Washington, DC

Orben RA, Paredes R, Roby DD, Irons DB, Shaffer SA (2015) Wintering North Pacific black-legged kittiwakes balance spatial flexibility and consistency. Mov Ecol 3:36

Ostfeld RS (1986) Territoriality and mating system of California voles. J Anim Ecol 55:691-706

* Payne MR (1977) Growth of a fur seal population. Philos Trans R Soc Lond B Biol Sci 279:67-79
Payo-Payo A, Genovart M, Bertolero A, Pradel R, Oro D (2016) Consecutive cohort effects driven by densitydependence and climate influence early-life survival in a long-lived bird. Proc R Soc B 283:20153042

* Phillips RA, Silk JRD, Phalan B, Catry P, Croxall JP (2004) Seasonal sexual segregation in two Thalassarche albatross species: competitive exclusion, reproductive role specialization or foraging niche divergence? Proc R Soc B 271:1283-1291

*Piatt JF, Wetzel J, Bell K, DeGange AR and others (2006) Predictable hotspots and foraging habitat of the endangered short-tailed albatross (Phoebastria albatrus) in the North Pacific: implications for conservation. Deep Sea Res II 53:387-398

* Porter JM, Coulson JC (1987) Long-term changes in recruitment to the breeding group, and the quality of recruits at a kittiwake Rissa tridactyla colony. J Anim Ecol 56: $675-689$

R Core Team (2016). R: a language and environment for statistical computing. R Foundation for Statistical Computing, Vienna; https://www.R-project.org/

* Renner M, Hunt GL Jr, Piatt JF, Byrd GV (2008) Seasonal and distributional patterns of seabirds along the Aleutian Archipelago. Mar Ecol Prog Ser 357:301-311

* Riotte-Lambert L, Weimerskirch H (2013) Do naive juvenile seabirds forage differently from adults? Proc R Soc B 280: 20131434

Santaella L, Sada AM (1991) A short-tailed albatross observed near San Benedicto Island, Revillagigedo Islands, Mexico. West Birds 22:33-34

Shaffer SA, Weimerskirch H, Costa DP (2001a) Functional significance of sexual dimorphism in wandering albatrosses, Diomedea exulans. Funct Ecol 15:203-210

Shaffer SA, Costa DP, Weimerskirch H (2001b) Behavioural factors affecting foraging effort of breeding wandering albatrosses. J Anim Ecol 70:864-874

Springer AM, McRoy CP, Flint MV (1996) The Bering Sea Green Belt: shelf-edge processes and ecosystem production. Fish Oceanogr 5:205-223

* Suryan RM, Fischer KN (2010) Stable isotope analysis and satellite tracking reveal interspecific resource partitioning of nonbreeding albatrosses off Alaska. Can J Zool 88: 299-305

Suryan RM, Sato F, Balogh GR, David Hyrenbach K, Sievert PR, Ozaki K (2006) Foraging destinations and marine habitat use of short-tailed albatrosses: a multi-scale approach using first-passage time analysis. Deep Sea Res II 53:370-386

* Suryan RM, Dietrich KS, Melvin EF, Balogh GR, Sato F, Ozaki K (2007) Migratory routes of short-tailed albatrosses: use of exclusive economic zones of North Pacific Rim countries and spatial overlap with commercial fisheries in Alaska. Biol Conserv 137:450-460

* Suryan RM, Anderson DJ, Shaffer SA, Roby DD and others (2008) Wind, waves, and wing loading: morphological specialization may limit range expansion of endangered albatrosses. PLOS ONE 3:e4016

* Terauds A, Gales R, Baker GB, Alderman RL (2006) Population and survival trends of wandering albatrosses (Diomedea exulans) breeding on Macquarie Island. Emu 106:211-219

Thorup K, Holland RA (2009) The bird GPS - long-range navigation in migrants. J Exp Biol 212:3597-3604

* Thorup K, Bisson IA, Bowlin MS, Holland RA, Wingfield JC, Ramenofsky M, Wikelski M (2007) Evidence for a navi- 
gational map stretching across the continental US in a migratory songbird. Proc Natl Acad Sci USA 104: 18115-18119

Tickell WLN (2000) Albatrosses. Yale University Press, New Haven, CT

USFWS (US Fish and Wildlife Service) (2014) Short-tailed albatross endangered species recovery plan: 5-year review. US Fish and Wildlife Service, Anchorage, AK

*VanderWerf EA, Young LC (2016) Juvenile survival, recruitment, population size, and effects of avian pox virus in Laysan albatross (Phoebastria immutabilis) on Oahu, Hawaii, USA. Condor 118:804-814

VLIZ (2014) Union of the ESRI country shapefile and the exclusive economic zones (version 2). www.marineregions. org/ (accessed on 21 March 2017)

Votier SC, Fayet AL, Bearhop S, Bodey TW and others (2017) Effects of age and reproductive status on individual foraging site fidelity in a long-lived marine predator. Proc R Soc B 284:20171068

Wanless S, Harris MP (1991) Diving patterns of full-grown and juvenile rock shags. Condor 93:44-48

Weimerskirch H, Jouventin P (1987) Population dynamics of the wandering albatross, Diomedea exulans, of the

Editorial responsibility: Rebecca Lewison, San Diego, California, USA
Crozet Islands: causes and consequences of the population decline. Oikos 49:315-322

Weimerskirch H, Salamolard M, Sarrazin F, Jouventin P (1993) Foraging strategy of wandering albatrosses through the breeding season: a study using satellite telemetry. Auk 110:325-342

*Weimerskirch H, Åkesson S, Pinaud D (2006) Postnatal dispersal of wandering albatrosses Diomedea exulans: implications for the conservation of the species. J Avian Biol 37:23-28

Wolf CM, Garland T, Griffith B (1998) Predictors of avian and mammalian translocation success: reanalysis with phylogenetically independent contrasts. Biol Conserv 86: 243-255

* Worton BJ (1995) A convex hull-based estimator of homerange size. Biometrics 51:1206-1215

* Young LC, Vanderlip C, Duffy DC, Afanasyev V, Shaffer SA (2009) Bringing home the trash: Do colony-based differences in foraging distribution lead to increased plastic ingestion in Laysan albatrosses? PLOS ONE 4:e7623

* Zador SG, Punt AE, Parrish JK (2008) Population impacts of endangered short-tailed albatross bycatch in the Alaskan trawl fishery. Biol Conserv 141:872-882

Submitted: May 8, 2017; Accepted: September 20, 2017

Proofs received from author(s): December 18, 2017 